\title{
Spectral pattern of paddy as response to drought condition: An experimental study
}

Arif Kurnia Wijayanto ${ }^{\mathrm{a}, \mathrm{b}}$, Lilik Budi Prasetyo ${ }^{\mathrm{a}}$, Yudi Setiawan ${ }^{\mathrm{a}, \mathrm{b}}$, Didi Darmadic, and Ahmad Junaedi ${ }^{\mathrm{d}}$

a Department Forest Resources Conservation and Ecotourism, Faculty of Forestry and Environment, IPB Darmaga Campus, Bogor, 16680, Indonesia

${ }^{\mathrm{b}}$ Environmental Research Center, IPB University, Kampus IPB Darmaga Bogor, 16680, Indonesia

c Program of Agronomy and Horticulture, Graduate School, Institut Pertanian Bogor. J1. Meranti, Kampus IPB Dramaga, Bogor 16680, Indonesia

${ }^{\mathrm{d}}$ Department of Agronomy and Horticulture, Faculty of Agriculture, Institut Pertanian Bogor. J1. Meranti, Kampus IPB Dramaga, Bogor 16680, West Java, Indonesia

\section{Article Info:}

Received: 16 - 03 - 2021

Accepted: 22 - 04 - 2021

Keywords:

Drought, paddy, spectral response

Corresponding Author: Arif Kurnia Wijayanto Department of Forests Resources Conservation and Ecotourism, Faculty of Forestry and Environment, IPB University; Tel. +62-251-8621262, 8621085 Email: akwijayanto@apps.ipb.ac.id

\begin{abstract}
Every single physical object has a different response to the electromagnetic wave emitted to it. The response is in the form of how it absorbs and reflects the energy in every range of wavelength. The absorption and reflection curve is known as a spectral pattern. The spectral pattern of each object can be used to determine the object. In agriculture, the spectral pattern of plants can be used to determine the health condition of the plant. Drought is one factor that can affect the health of the plant. By identifying the spectral pattern of the plants, the effect of drought on paddy can be identified. This experimental study tried to identify the spectral pattern of some varieties of paddy and different growth stages. A spectrophotometer with a wavelength range of 350-1052 $\mathrm{nm}$ was used. Four varieties of paddy were planted in a greenhouse and being treated in drought conditions from the stage of vegetative, generative, and reproductive. Based on the result, the spectral response from the generative phase of all varieties gave the most different pattern compared to the control. This result was compromising the rapid detection of paddy fields affected by drought using optical remote sensing data. Especially for plants in the stage of generative.
\end{abstract}

How to cite (CSE Style $8^{\text {th }}$ Edition):

Wijayanto AK, Prasetyo LB, Setiawan Y, Darmadi D, Junaedi A. 2021. Spectral response of paddy in drought condition: An experimental study. JPSL 11(1): 83-92. http://dx.doi.org/10.29244/jps1.11.1.83-92.

\section{INTRODUCTION}

Every single physical object has a different response to the electromagnetic wave emitted to it. The response is how it absorbs and reflects the energy in every range of wavelength. The absorption and reflection curve is known as the spectral pattern (Huete, 2004). The spectral pattern of each object can be used to determine the object. In agriculture, the spectral pattern of plants can be used to determine the health condition of the plant. The effect of the anomaly of photosynthesis activity can be seen physically. For instance, as resistant to drought conditions, the plant will roll its leaves (Nio and Lenak, 2014). By rolling the leaves, a plant can decrease evapotranspiration due to an increase in water absorption. This rolling is also an effect of drought, which can be monitored in the visible light spectrum. Plants tend to absorb the visible spectrum of waves mainly in the blue and red spectrum and reflect the Near Infra-Red (NIR) spectrum (Espinoza et al., 
2017; Maes and Steppe, 2019; Tran et al., 2017). However, the effect itself already occurs before the leaves started to roll. This cannot be monitored in the visible light spectrum, but it can be monitored in the invisible light spectrum such as NIR. In normal conditions, the NIR spectrum (wavelength 750-1500 nm) is absorbed by the plants due to its water content. The characteristics of the red and near infra-red channels in this vegetation are then used to calculate the vegetation index, which shows the level of the greenness of the vegetation (Congalton, 2015; Lillesand and Kiefer, 1994). Penuelas et al. (1993) found that the reflectance at the 950-970 nm of wavelength, which is in the range of NIR spectrum, is the indicator of water status in plants and then proposed the Water Band Index (WBI) (Penuelas et al., 1997). Other indexes proposed to estimate water content in plant leaves are Normalised Difference Water Index (NDWI) (Gao, 1996), Normalized Multiband Drought Index (NMDI) (Wang and Qu, 2007), Normalized Difference Infrared Index (NDII), and Moisture Stress Index (MSI) (Hunt and Rock, 1989).

Drought is one factor that can affect the health of paddy plants. For example, as a form of drought resistance, paddy plants will show rolling leaves symptoms (Anusha and Bharathi, 2020). By rolling the leaves, paddy plants can reduce evapotranspiration rate due to increased water absorption in dry soil. This rolling of the leaves is an example of the effects of drought on paddy plants which can be observed in the visible light spectrum. Paddy has different spectral responses depends on plant age, varieties, and physiological conditions. Paddy and other plants, in general, absorb more light in the spectrum of red and blue for photosynthesis purposes. It is because red and blue lights are effective for photosynthesis (Reece and Campbell, 2012). But basically, the impact of drought on paddy plants has occurred before leaf rolling. This impact cannot be observed in the visible light spectrum but is observed in the invisible light spectrum such as near-infrared (NIR). The reflectance value increases in the near-infrared (NIR) spectrum (wavelength 750-1500 nm). This is following the characteristics of the NIR spectrum which tends to be completely absorbed by water, resulting in a low reflectance value. In drought conditions, with a low water content, it will result in a high NIR reflectance spectrum (Orych et al., 2014; Jacquemoud and Ustin, 2019).

By identifying the spectral pattern of the plants, the effect of drought on paddy can be identified. This experimental study tried to identify the spectral pattern of some varieties of paddy in different growth stages.

\section{METHODOLOGY}

\section{Study Location and Experiment Design}

The experiment was done in a greenhouse located in Bogor, West Java, Indonesia. There were four varieties of paddy observed in the experiment: IPB 9G, Hipa 19, Jatiluhur, and IPB 3S treated in three repetitions each for treatment and control. For each plant, data acquisition was repeated three times. Hence, there would be nine data for each paddy variety, both for treatment and control. The plants were in three different growth stages: vegetative (P1), reproductive (P2), and generative (P3). Data acquisition was done before the drought treatment on September $11^{\text {th }}, 2019$, and on October $14^{\text {th }}, 2019$, or one week after the treatment. 


\begin{tabular}{|c|c|c|c|c|c|c|}
\hline $\begin{array}{c}\text { P3 } \\
\text { TREATMENT }\end{array}$ & $\begin{array}{l}\text { Jatiluhur } \\
\text { IPB 9G }\end{array}$ & $\begin{array}{l}\text { Hipa } 19 \\
\text { IPB } 35\end{array}$ & $\begin{array}{l}\text { Jatiluhur } \\
\text { Hipa } 19\end{array}$ & $\begin{array}{l}\text { IPB 9G } \\
\text { IPB 3S }\end{array}$ & $\begin{array}{l}\text { Jatiluhur } \\
\text { IPB } 35\end{array}$ & $\begin{array}{l}\text { IPB 9G } \\
\text { Hipa } 19\end{array}$ \\
\hline $\begin{array}{c}\text { P3 } \\
\text { CONTROL }\end{array}$ & $\begin{array}{l}\text { IPB 3S } \\
\text { Hipa } 19\end{array}$ & $\begin{array}{l}\text { IPB 9G } \\
\text { Jatiluhur }\end{array}$ & $\begin{array}{l}\text { IPB 9G } \\
\text { IPB 3S }\end{array}$ & $\begin{array}{l}\text { Jatiluhur } \\
\text { Hipa } 19\end{array}$ & $\begin{array}{l}\text { Hipa } 19 \\
\text { Jatiluhur }\end{array}$ & $\begin{array}{l}\text { IPB 9G } \\
\text { IPB 3S }\end{array}$ \\
\hline $\begin{array}{c}\text { P2 } \\
\text { TREATMENT }\end{array}$ & $\begin{array}{l}\text { IPB 3S } \\
\text { Jatiluhur }\end{array}$ & $\begin{array}{l}\text { IPB 9G } \\
\text { Нipa } 19\end{array}$ & $\begin{array}{l}\text { Jatiluhur } \\
\text { IPB 3S }\end{array}$ & $\begin{array}{l}\text { Hipa } 19 \\
\text { IPB 9G }\end{array}$ & $\begin{array}{l}\text { IPB 9G } \\
\text { Jatiluhur }\end{array}$ & $\begin{array}{l}\text { IPB 3S } \\
\text { Hipa } 19\end{array}$ \\
\hline $\begin{array}{c}\text { P2 } \\
\text { CONTROL }\end{array}$ & $\begin{array}{l}\text { IPB 3S } \\
\text { IPB 9G }\end{array}$ & $\begin{array}{l}\text { Hipa } 19 \\
\text { Jatiluhur }\end{array}$ & $\begin{array}{l}\text { Jatiluhur } \\
\text { IPB 3S }\end{array}$ & $\begin{array}{l}\text { IPB 9G } \\
\text { Hipa } 19\end{array}$ & $\begin{array}{l}\text { IPB } 35 \\
\text { Hipa } 19\end{array}$ & $\begin{array}{l}\text { Jatiluhur } \\
\text { IPB 9G }\end{array}$ \\
\hline $\begin{array}{c}\text { P1 } \\
\text { TREATMENT }\end{array}$ & $\begin{array}{l}\text { IPB 9G } \\
\text { IPB 3S }\end{array}$ & $\begin{array}{l}\text { Jatiluhur } \\
\text { Hipa } 19\end{array}$ & $\begin{array}{l}\text { IPB 3S } \\
\text { Jatiluhur }\end{array}$ & $\begin{array}{l}\text { IPB 9G } \\
\text { Hipa } 19\end{array}$ & $\begin{array}{l}\text { IPB 3S } \\
\text { Jatiluhur }\end{array}$ & $\begin{array}{l}\text { Hipa } 19 \\
\text { IPB 9G }\end{array}$ \\
\hline $\begin{array}{c}\text { P1 } \\
\text { CONTROL }\end{array}$ & $\begin{array}{l}\text { IPB 9G } \\
\text { Hipa } 19\end{array}$ & $\begin{array}{l}\text { IPB 3S } \\
\text { Jatiluhur }\end{array}$ & $\begin{array}{l}\text { IPB 9G } \\
\text { IPB 3S }\end{array}$ & $\begin{array}{l}\text { Hipa } 19 \\
\text { Jatiluhur }\end{array}$ & $\begin{array}{l}\text { Jatiluhur } \\
\text { Hipa } 19\end{array}$ & $\begin{array}{l}\text { IPB 9G } \\
\text { IPB 3S }\end{array}$ \\
\hline
\end{tabular}

Figure 1 Experiment design

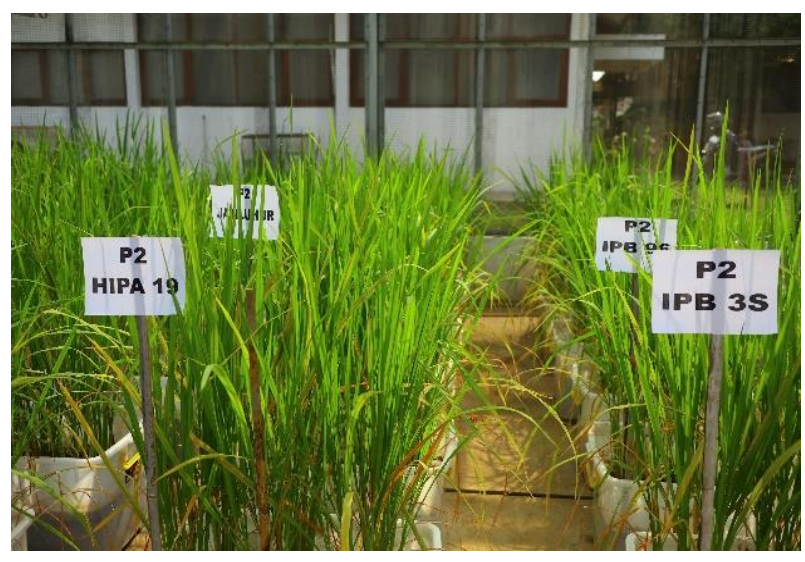

Figure 2 Experimental plants in the greenhouse

\section{Measurement Instrument}

The tool used in the experiment was a spectroradiometer EKO Instruments, namely MS-720. The MS720 portable spectroradiometer is designed to measure the spectral irradiance in the range from visible (red, green, and blue) to Near-Infrared (NIR). It is mainly used for geological data acquisition, vegetation, oceanography, remote sensing, and other applications. It has a wavelength range from 350 to $1050 \mathrm{~nm}$, optical resolution of less than $10 \mathrm{~nm}$, wavelength accuracy of less than $0.3 \mathrm{~nm}$, and has three different aperture options: 45,25 , and 10 degrees. The aperture of 45 degrees was used in this experiment. To avoid the shadow of the operator, an approximately 2 meters monopod was used. The instrument should be at the height of $1.2 \mathrm{~m}$ above the plants. By using 45 degrees of aperture, the Field of View (FOV) would be approximately $0.5 \mathrm{~m}$. This range completely covered the area of plants. The illustration of data acquisition is shown in Figure 3. A piece of black fabric was also used to avoid reflectance from non-plant objects, as shown in Figure 4.

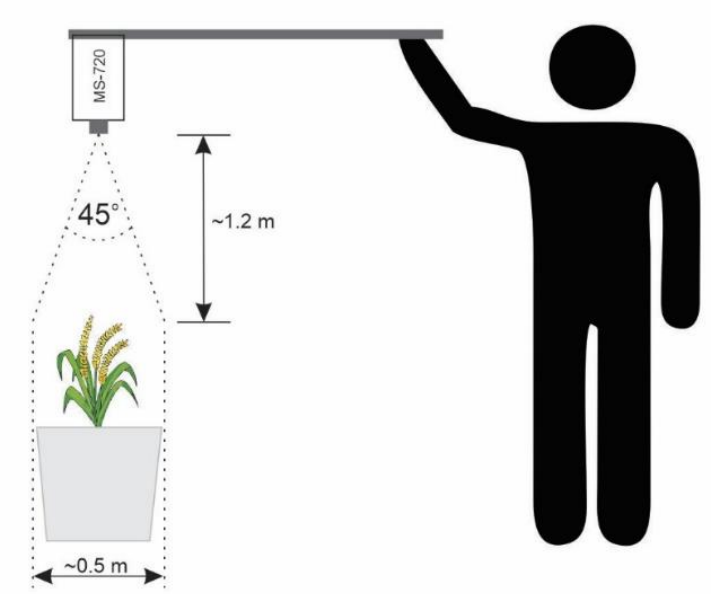

Figure 3 Illustration of data acquisition using MS720 spectroradiometer

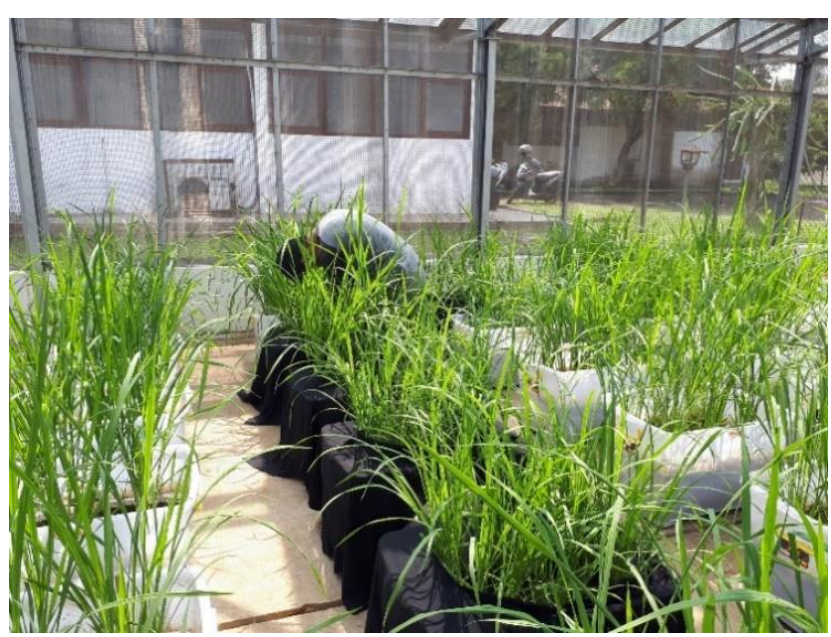

Figure 4 Application of black fabric to avoid reflectance from the non-plant object

\section{Data Processing}

The output of the MS-720 spectroradiometer is not in the form of reflectance but the form of irradiance. Hence, by assuming the Lambertian surface, reflection from paddy $(\rho)$ can be estimated by using the following formula:

$$
\rho=\pi l_{d} / l_{u} \Omega
$$


Information: $l_{d}=$ lights reflected from plants, $l_{u}=$ lights hit the plants, $\Omega=$ solid View Port viewing angle

Data processing was carried out in R software. The reflectance of each sample with the same varieties and wavelength was averaged. To get the reflectance of each spectrum of light, the wavelengths were divided into four groups based on several wavelength ranges, as shown in Table 1. The reflectance of each spectrum was obtained by averaging the reflectance data in the wavelength range. The reflectance difference of post and pre-treatment in each growth stage was calculated to identify the most determining spectrum to drought. Figure 5 shows the overall flow of data processing in this study.

Table 1 Division of data based on wavelength

\begin{tabular}{cc}
\hline Spectrum & Wavelength $(\mathrm{nm})$ \\
\hline Blue & $450-510$ \\
Green & $530-590$ \\
Red & $640-670$ \\
NIR & $850-880$ \\
\hline
\end{tabular}

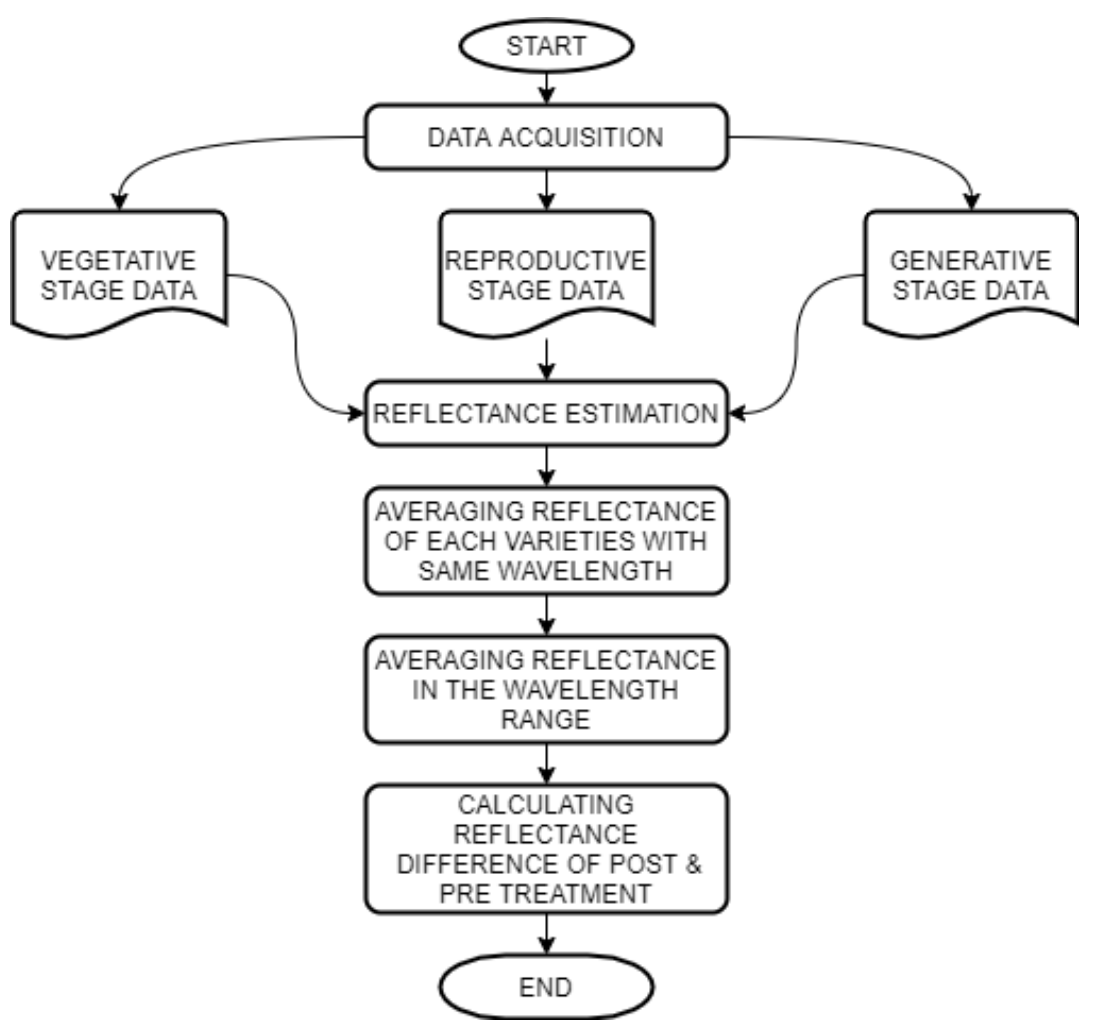

Figure 4 Data processing flowchart

\section{RESULTS AND DISCUSSION}

\section{Spectral Pattern}

Experiment on a laboratory scale has been carried out to see several paddy varieties' spectral response to drought treatment. The result which was obtained is a distinctive pattern as a response to paddy plants due to drought stress. 


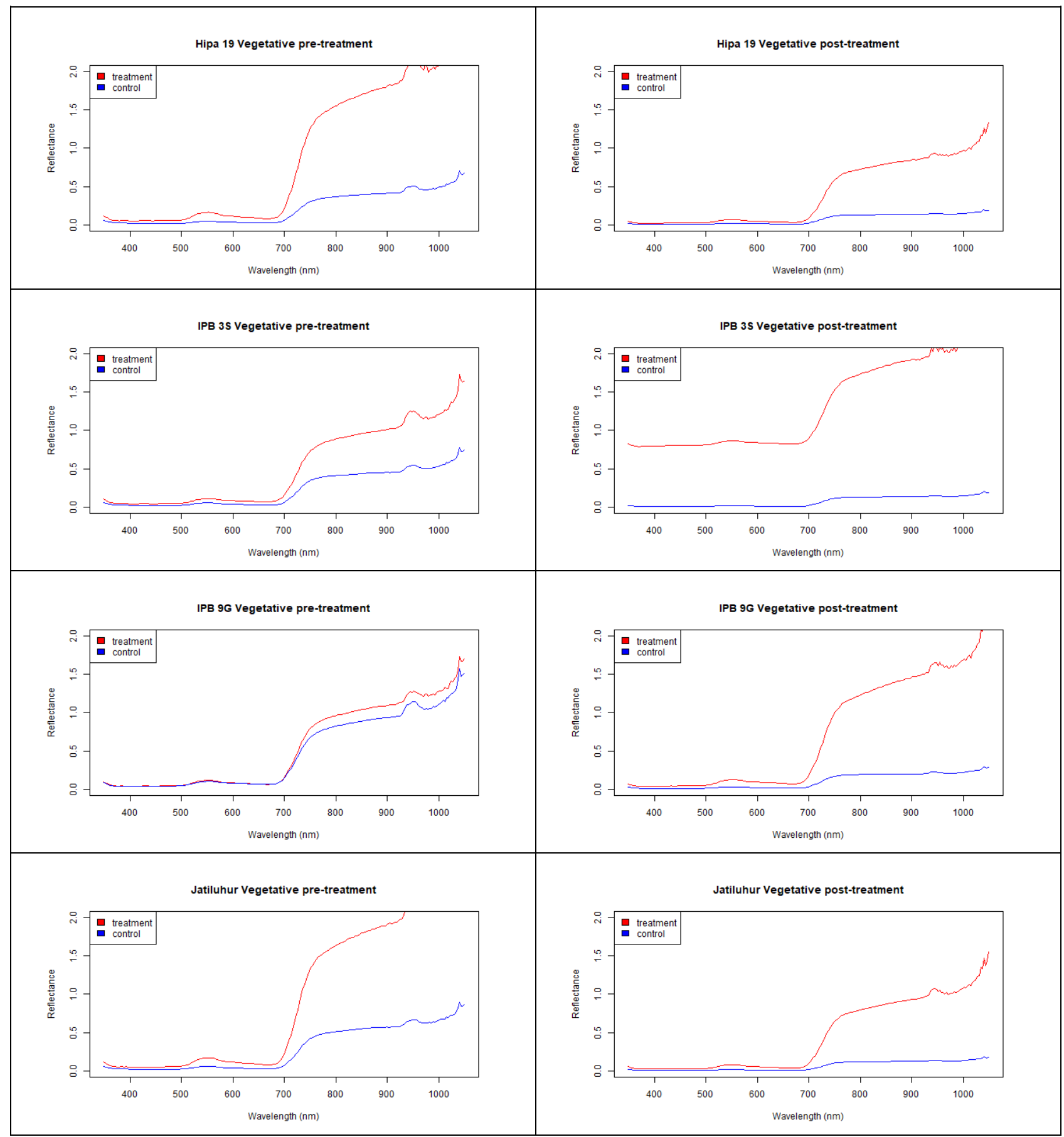

Figure 6 The spectral response of several paddy varieties in the vegetative phase to drought stress

Based on this study, the most different spectral responses were found in the generative growth phase. In this phase, plants give a uniform response, namely an increase in reflectance in the red-light spectrum (wavelength $620-750 \mathrm{~nm}$ ). The increase in red-light spectrum reflectance is followed by a decrease in the nearinfrared (NIR) spectrum with a wavelength of 700-1 $100 \mathrm{~nm}$. In the blue wavelength range (600-608 $\mathrm{nm}$ ) there was also an increase in reflectance. This indicates a change in photosynthesis activity that occurs in plants. Changes in photosynthesis activity are caused by leaf structure changes (Jacquemoud and Ustin, 2019) and biochemical content in plant leaves. 
Wijayanto AK, Prasetyo LB, Setiawan Y

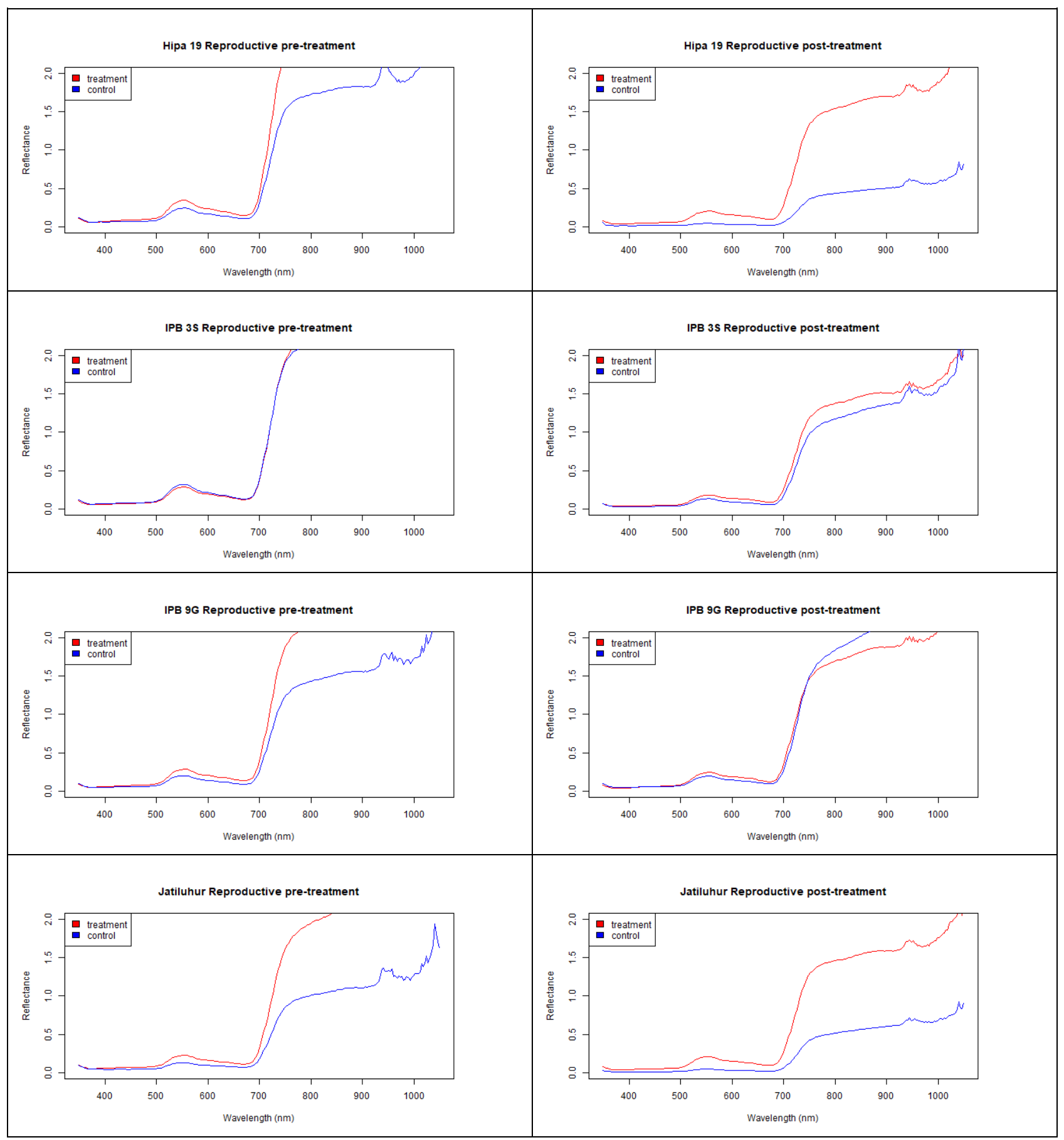

Figure 7 The spectral response of several paddy varieties in the reproductive phase to drought stress

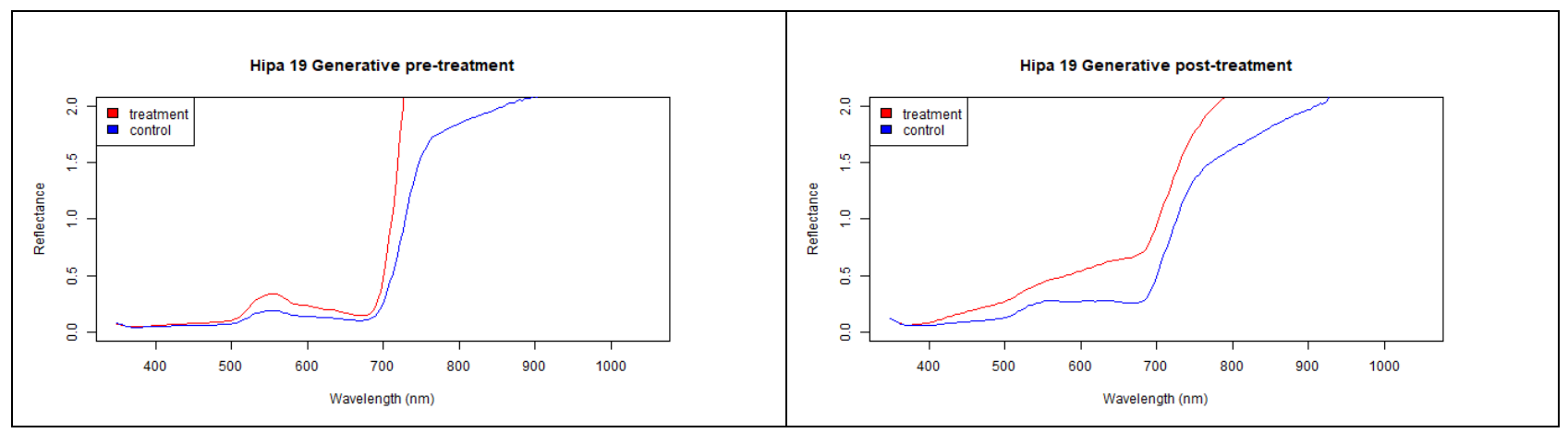

88 


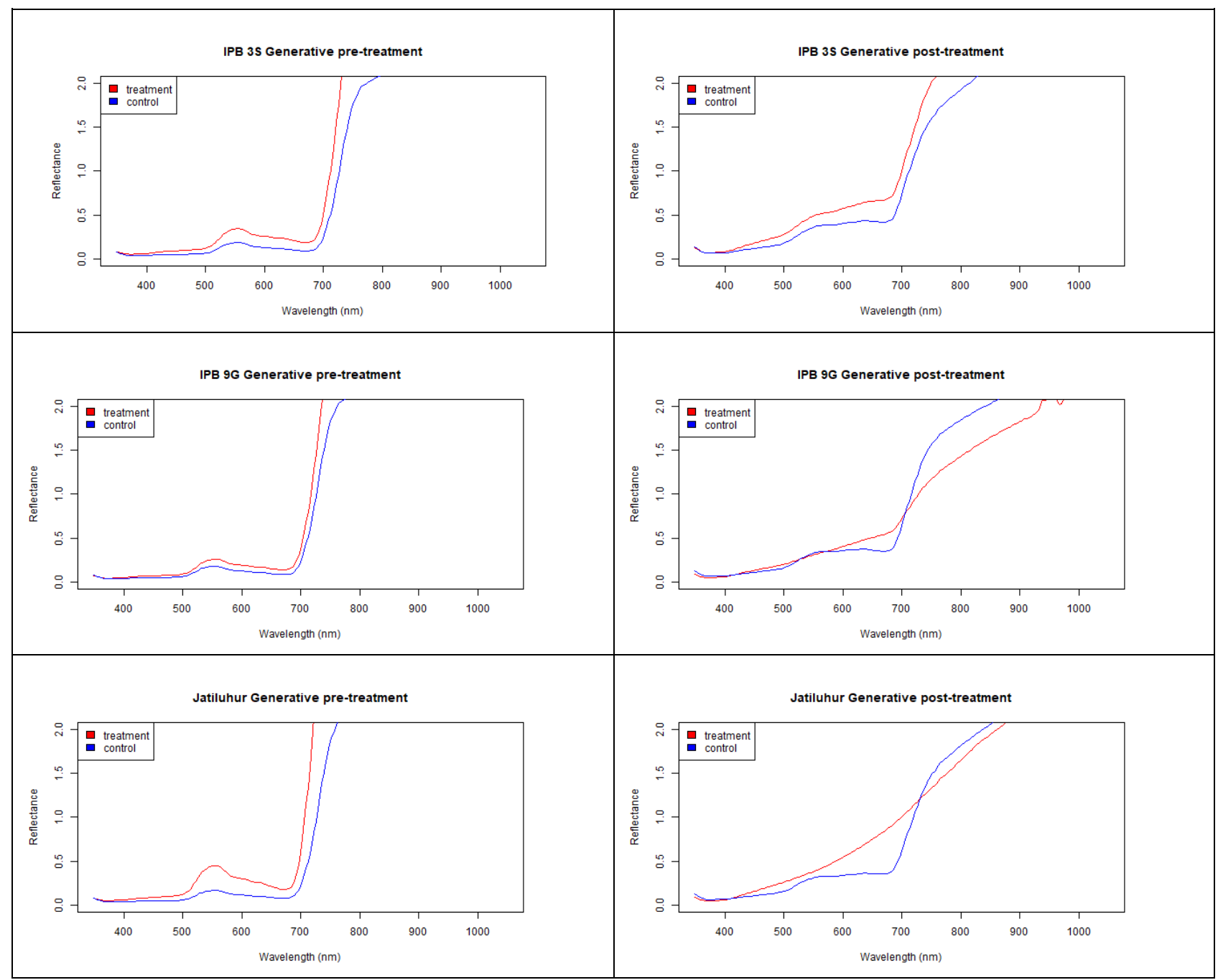

Figure 8 The spectral response of several paddy varieties in the generative phase to drought stress

\section{Reflectance Difference of Post and Pre-treatment}

In this study, the reflectance difference of post and pre-treatment in each growth stage was calculated by grouping the wavelength into four groups of the spectrum to identify the most determining spectrum to drought. A positive difference indicates decreasing in reflectance before and after the drought treatment. Otherwise, a negative difference indicates the increment of reflectance after treatment.

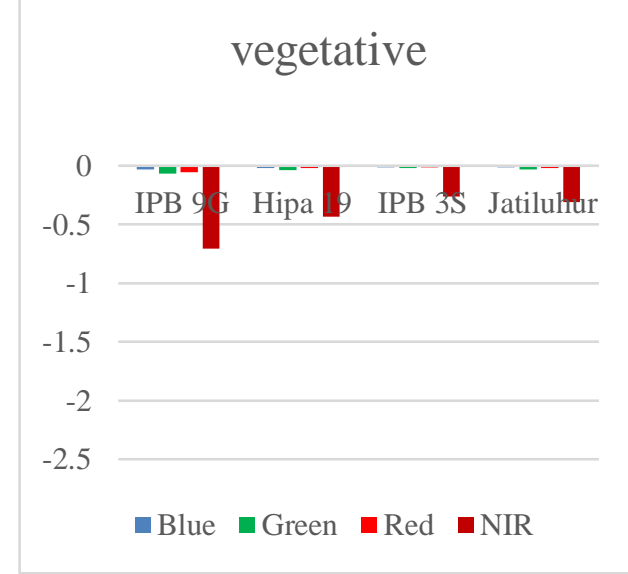

reproductive

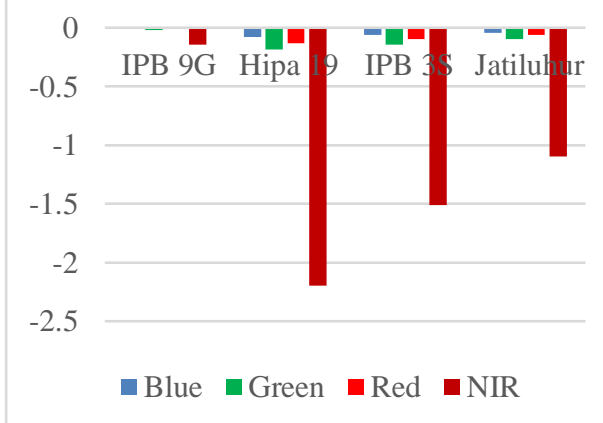


Figure 5 Reflectance difference of post and pre-treatment in the vegetative and reproductive stage

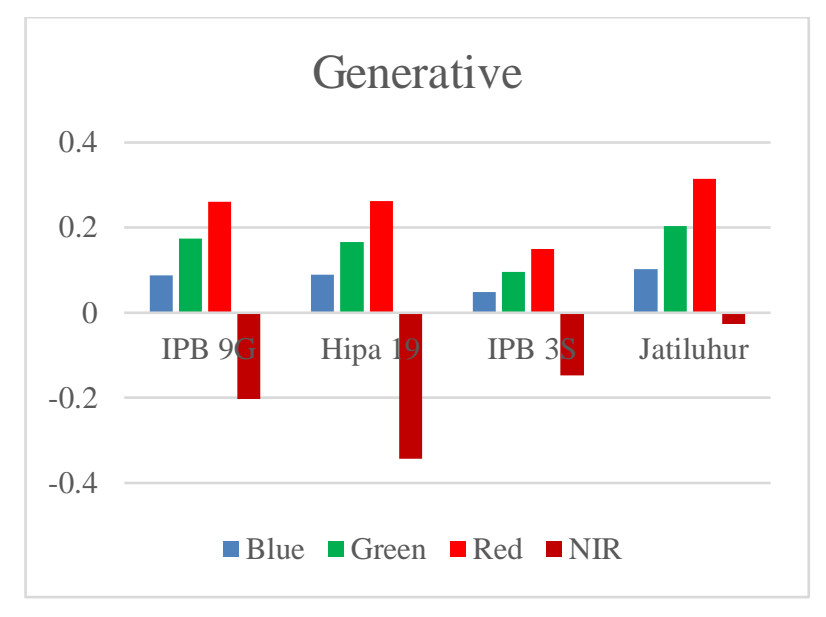

Figure 6 Reflectance difference of post and pre-treatment in generative stage

The negative difference is found in the vegetative and reproductive growth stages. The reflectance from all spectrum range was decreased after the treatment. A different result was obtained from the generative stage. All of the wavelength spectrum reflectances increased, except the NIR spectrum. The largest drop was from the red-light spectrum, for all varieties. This result fits the theory that unhealthy plants absorb the less visible light spectrum and reflect it more than healthy plants. The red-light spectrum was the highest increase compared to the other light spectrum. This pattern was the same for all of the paddy varieties.

\section{WBI Calculation}

The simple Water Band Index (WBI) proposed by Penuelas et al. (1997) was also calculated in this study. The WBI or Water Index (WI) was presented to estimate Plant Water Content (PWC) in ground-based. It is calculated by comparing the reflectance of $900 \mathrm{~nm}$ to $970 \mathrm{~nm}$ wavelength. Other water indexes such as Normalized Difference Water Index (NDWI), Moisture Stress Index (MSI), Normalized Difference Infrared Index (NDII), and Normalized Multi-band Drought Index (NMDI) were not calculated in this study due to the limitation of the spectroradiometer instrument.

Table 2 Water Index from all varieties and growth stage

\begin{tabular}{cccccc}
\hline Stage & & IPB 9G & Jatiluhur & Hipa 19 & IPB 3S \\
\hline \multirow{2}{*}{ Vegetative } & Pre & 0.906 & 0.903 & 0.900 & 0.883 \\
\cline { 2 - 6 } & Post & $0.932^{*}$ & $0.941^{*}$ & $0.948^{*}$ & $0.958^{*}$ \\
\hline \multirow{2}{*}{ Reproductive } & Pre & 0.929 & 0.935 & 0.936 & 0.930 \\
\cline { 2 - 6 } & Post & $0.965^{*}$ & $0.967^{*}$ & $0.966^{*}$ & $0.968^{*}$ \\
\hline \multirow{2}{*}{ Generative } & Pre & $0.984^{*}$ & $0.995^{*}$ & $0.982^{*}$ & $0.965^{*}$ \\
\cline { 2 - 6 } & Post & 0.899 & 0.894 & 0.901 & 0.897 \\
\hline
\end{tabular}

Note: asterisk indicates a larger value

From Table 2, the WI value varies in the range of 0.8 to 1.0 , which is indicated as a normal condition based on WI value interpretation. Similar patterns were found from the vegetative and reproductive stage and all paddy varieties, which give more significant value from post-treatment, indicating the WI increase after treatment. Different results come from the generative stage, where decreasing WI is provided by all varieties of paddy. This result is similar to the result of the spectral pattern, which offered different results from the 90 
generative growth stage. However, the increasing or decreasing value of WI in this study was not significant. The largest difference was found from Jatiluhur in the generative stage, which decreased by 0.101 , followed by Hipa 19, which decreased by 0.081 . The largest increment was found from IPB 3S, which increased by 0.075 followed by Hipa 19, which increased by 0.048 . Champagne et al. (2001) stated that at the canopy scale, WI has low sensitivity to a low water content of the individual leaf because it is strongly influenced by canopy structure.

\section{CONCLUSION}

Four varieties of paddy in this study gave a typical response to drought treatment. The most typical spectral responses were found in the generative growth stage. In the generative stage, four varieties' spectral response increased in the visible light spectrum (red, green, blue) as a response of the plants after treated by drought conditions. The highest increase was found from the red-light spectrum. It indicates the red-light spectrum is the most determining spectrum in the detection of drought that affects paddy in the generative growth stage. This result was compromising the rapid detection of paddy fields affected by drought using optical remote sensing data. Especially for paddy plants in the stage of generative.

WI provided low sensitivity to indicate water stress in paddy in this study. However, WI promises the detection of the growth stage of paddy under drought stress. WI can be used to distinguish the vegetative/reproductive and generative stages of four varieties of paddy in this study.

\section{ACKNOWLEDGMENT}

Thanks are conveyed to the Ministry of Research and Technology/National Research and Innovation Agency for research grants for the Higher Education Leading Basic Research (PTUPT) scheme for the 2020 Fiscal Year. This work was conducted under the SATREPS project, "Development and Implementation of New Damage Assessment Process in Agricultural Insurance as Adaptation to Climate Change for Food Security".

\section{REFERENCE}

Anusha N, Bharathi B. 2020. Flood detection and flood mapping using multi-temporal synthetic aperture radar and optical data. The Egyptian Journal of Remote Sensing and Space Science. 23(2): 207-219. doi: https://doi.org/10.1016/j.ejrs.2019.01.001.

Champagne C, Pattey E, Bannari A, Stratchan IB. 2001. Mapping crop water status: Issues of scale in the detection of crop water stress using hyperspectral indices. Proceedings of the 8th International Symposium on Physical Measurements and Signatures in Remote Sensing. 79-84.

Congalton RG. 2015. Remote sensing and image interpretation. 7th edition. Photogrammetric Engineering \& Remote Sensing. 81(8): 615-616. doi: https://doi.org/10.14358/pers.81.8.615.

Espinoza CZ, Khot LR, Sankaran S, Jacoby PW. 2017. High resolution multispectral and thermal remote sensing-based water stress assessment in subsurface irrigated grapevines. Remote Sensing. 9: 1-15. doi: https://doi.org/10.3390/rs9090961.

Gao BC. 1996. NDWI-a normalized difference water index for remote sensing of vegetation liquid water from space. Remote Sensing of Environment. 58: 257-266. doi: https://doi.org/10.1016/S00344257(96)00067-3.

Huete AR. 2004. 11-remote sensing for environmental monitoring. Environmental Monitoring and Characterization. 183-206. doi: https://doi.org/https://doi.org/10.1016/B978-012064477-3/50013-8.

Hunt ER, and Rock BN. 1989. Detection of changes in leaf water content using near- and middle-infrared reflectances. Remote Sensing of Environment. 30: 43-54. doi: https://doi.org/10.1016/00344257(89)90046-1. 
Jacquemoud S, Ustin S. 2019. Leaf Optical Properties. Cambridge (UK): Cambridge University Press.

Lillesand TM, Kiefer RW. 1994. Remote Sensing and Image Interpretation. 3rd ed. Chichester (UK): Wiley.

Maes WH, Steppe K. 2019. Perspectives for remote sensing with unmanned aerial vehicles in precision agriculture. Trends in Plant Science. 24(2): 152-164. doi: https://doi.org/10.1016/j.tplants.2018.11.007.

Nio SA, Lenak Aa. 2014. Penggulungan daun pada tanaman monokotil saat kekurangan air (leaf rolling in monocotyledon plants under water deficit). JURNAL BIOS LOGOS. 4(2): 1-8. doi: https://doi.org/10.35799/jbl.4.2.2014.5539.

Orych A, Walczykowski P, Dąbrowski R, Kutyna E. 2014. Using plant spectral response curves in detecting plant stress. Ecological Questions. 17: 67-74.

Penuelas J, Filella I, Biel C, Serrano L, Save R. 1993. The reflectance at the 950-970 Nm region as an indicator of plant water status. International Journal of Remote Sensing. 14(10): 1887-1905. doi: https://doi.org/10.1080/01431169308954010.

Penuelas J, Pinol J, Ogaya R, Filella I. 1997. Estimation of plant water concentration by the reflectance water index WI (R900/R970). International Journal of Remote Sensing. 18(13): 2869-2875. doi: https://doi.org/10.1080/014311697217396.

Reece JB, Campbell NA. 2012. Campbell Biology. 9th ed. Melbourne (AU): Pearson Australia Frenchs Forest, N.S.W.

Tran HT, Campbell JB, Tran TD, Tran HT. 2017. Monitoring drought vulnerability using multispectral indices observed from sequential remote sensing (case study: Tuy Phong, Binh Thuan, Vietnam)." GIScience and Remote Sensing. 54(2): 167-184. doi: https://doi.org/10.1080/15481603.2017.1287838.

Wang L, Qu JJ. 2007. NMDI: A normalized multi-band drought index for monitoring soil and vegetation moisture with satellite remote sensing. Geophysical Research Letters. 34:1-5. doi: https://doi.org/10.1029/2007GL031021. 